\title{
ANALISIS DAN PERANCANGAN DATA ARCHITECTURE DAN APPLICATION ARCHITECTURE MENGGUNAKAN THE OPEN GROUP ARCHITECTURE FRAMEWORK ARCHITECTURE DEVELOPMENT METHOD (TOGAF ADM) PADA PT SHAFCO MULTI TRADING
}

\author{
${ }^{1}$ I Gede Mindrayasa, ${ }^{2}$ Murahartawaty, ${ }^{3}$ Ridha Hanafi \\ Program Studi Sistem Informasi, Fakultas Rekayasa Industri, Universitas Telkom \\ ${ }^{1}$ mindrayasa@gmail.com, ${ }^{2}$ murahartawaty@gmail.com,, ${ }^{3}$ ridhanafi@gmail.com
}

\begin{abstract}
Abstrak--PT Shafco Multi Trading menyadari semakin pentingnya pengelolaan data dan aplikasi pada perusahaan sehingga perlunya meningkatkan kualitas dan efektivitas penerapan sistem informasi yang ada dalam menjalankan kegiatan proses bisnis perusahaan. Arsitektur enterprise diperlukan dalam upaya mendukung daya saing dan transformasi bisnis. Arsitektur enterprise ini bertujuan untuk membentuk keselarasan antara penerapan teknologi informasi terhadap bisnis bagi kebutuhan perusahaan. Analisis dan perancangan pada arsitektur enterprise bersifat menyeluruh dalam skala perusahaan sehingga membantu keberhasilan pengembangan dan pelaksanaan strategi pada perusahaan. Dalam penelitian ini, konsep aristektur enterprise menjadi panduan dalam setiap pengambilan data maupun informasi serta melakukan verifikasi dengan pihak perusahaan untuk memastikan hasil yang dicapai memang sesuai dengan keinginan perusahaan dan juga konsep ideal arsitektur enterprise. Metodologi yang tepat dibutuhkan untuk melakukan perancangan arsitektur enterprise yaitu dalam hal ini adalah TOGAF ADM. Framework ini fokus pada implementasi dan proses. TOGAF ADM memiliki empat komponen utama adalah business architetcure, data architetcure, application architecture, serta technology architecture. Perancangan enterprise architecture menghasilkan blueprint yang berguna dalam mengembangkan perusahaan.
\end{abstract}

Kata Kunci: Arsitektur Enterprise, TOGAF ADM, Arsitektur Data, Arsitektur Aplikasi, PT Shafco Multi Trading.

\section{Pendahuluan}

PT Shafco Multi Trading adalah sebuah perusahaan yang berhasil membangun sebuah bisnis di bidang busana dan dimulai dengan brand Shafira. PT Shafco Multi Trading telah mengembangkan lini bisnis yaitu "ZOYA", yang dikembangkan melalui sistem bisnis franchise yang hingga sekarang telah memiliki lebih dari 70 cabang yang tersebar di seluruh Indonesia. Berdasarkan dari pencapaian perusahaan tersebut dapat dikatakan perusahaan PT Shafco Multi Trading sedang mengalami perkembangan yang pesat. Hal itu akan menjadikan peran teknologi informasi semakin diperhitungkan. Semua kegiatan proses bisnis mulai dari Products Development, pengadaan Raw Material, tahap Production, Storage and Distribution, Store, dan sampai ke pelanggan harus berjalan sesuai yang diharapkan. Namun, dalam implementasi saat ini, pengelolaan terhadap data dan aplikasi masih perlu pengembangan untuk meningkatkan efektifitias dan efesiensi proses bisnis pada perusahaan.

Pentingnya pengembangan arsitektur data dan arsitektur aplikasi dapat terlihat dalam beberapa kondisi seperti pengorganisasian data dalam perusahaan. Dalam penelitian ini, peneliti mengidentifikasi seluruh data yang ada dalam perusahaan dan dalam hasilnya masih ada beberapa fungsi bisnis yang belum memiliki komponen data di dalamnya. Itu dikarenakan belum adanya perancangan arsitektur data secara menyeluruh. Begitu juga dengan arsitektur aplikasi, dalam penelitian ini kami menilai tanpa adanya perancangan arsitektur aplikasi, perusahaan belum dapat mengidentifikasi kebutuhan aplikasi secara mendetail sehingga ada beberapa fungsi bisnis yang tidak diakomodasi oleh aplikasi yang ada dalam perusahaan. Di samping itu juga, masih diperlukan beberapa integrasi dalam aplikasi guna menghindari redundansi data. Berdasarkan kondisi di atas, PT Shafco Multi Trading memerlukan perancangan arsitektur enterprise ini guna memperbaiki sistem dengan menyelaraskan proses bisnis dengan implementasi teknologi khususnya di bidang arsitektur data dan arsitektur aplikasi. Penelitian ini bertujuan untuk merancang dokumen enterprise architecture pada dua komponen utama, yaitu data architecture dan application architecture. 


\section{METODE PENELITIAN}

\section{A. Enterprise Architecture}

Arsitektur enterprise adalah suatu pernyataan tentang bagaimana perusahaan menyelaraskan implementasi TI dengan proses bisnis yang ada di perusahaan tersebut. Berikut ini adalah definisi arsitektur enterprise dari berbagai sumber.

1. Basis aset informasi strategis, yang menentukan misi, informasi dan teknologi yang dibutuhkan untuk melaksanakan misi, dan proses transisi untuk mengimplementasikan teknologi baru sebagai tanggapan terhadap perubahan kebutuhan misi [1].

2. Arsitektur enterprise adalah logika pengorganisasian untuk proses bisnis dan infrastruktur TI yang mencerminkan integrasi dan standarisasi persyaratan model operasi perusahaan. Model operasi adalah keadaan integrasi proses bisnis dan standarisasi proses bisnis yang diinginkan untuk menyediakan barang dan layanan kepada pelanggan [2].

3. Pemahaman tentang semua perbedaan elemen yang mendukung pengembangan enterprise dan bagaimana elemen-elemen tersebut berhubungan [3].

4. Arsitektur enterprise adalah pendekatan terstruktur untuk menguraikan setiap kebutuhan sistem sehingga dapat digunakan untuk merancang dan mengembangkan sistem yang kompleks agar menjadi lebih sederhana [4].

\section{B. TOGAF ADM}

The Open Group Architecture Framework (TOGAF) adalah arsitektur framework TOGAF menyediakan method dan tools untuk membangun, mengelola dan mengimplementasikan serta pemeliharaan arsitektur enterprise [3]. Salah satu elemen kunci dari TOGAF adalah Architecture Development Method (ADM) yang memberikan gambaran spesifik untuk proses pengembangan arsitektur enterprise [5]. Tahapan TOGAF ADM terdiri dari :

1. Preliminary Stage

2. Architecture Vision

3. Business Architecture

4. Information System Architecture

5. Technology Architecture

6. Opportunities and Solution

7. Migration Planning

8. Implementation Governance

9. Architecture Change Management

\section{Model Konseptual}

Model Konseptual adalah gambaran logis permasalahan yang dinyatakan dalam seperangkat konsep yang berdasarkan atas aspek hipotesis dan teoritis. Untuk menghasilkan output yang sesuai dengan tujuan penelitian dibutuhkan kerangka berpikir secara ringkas.

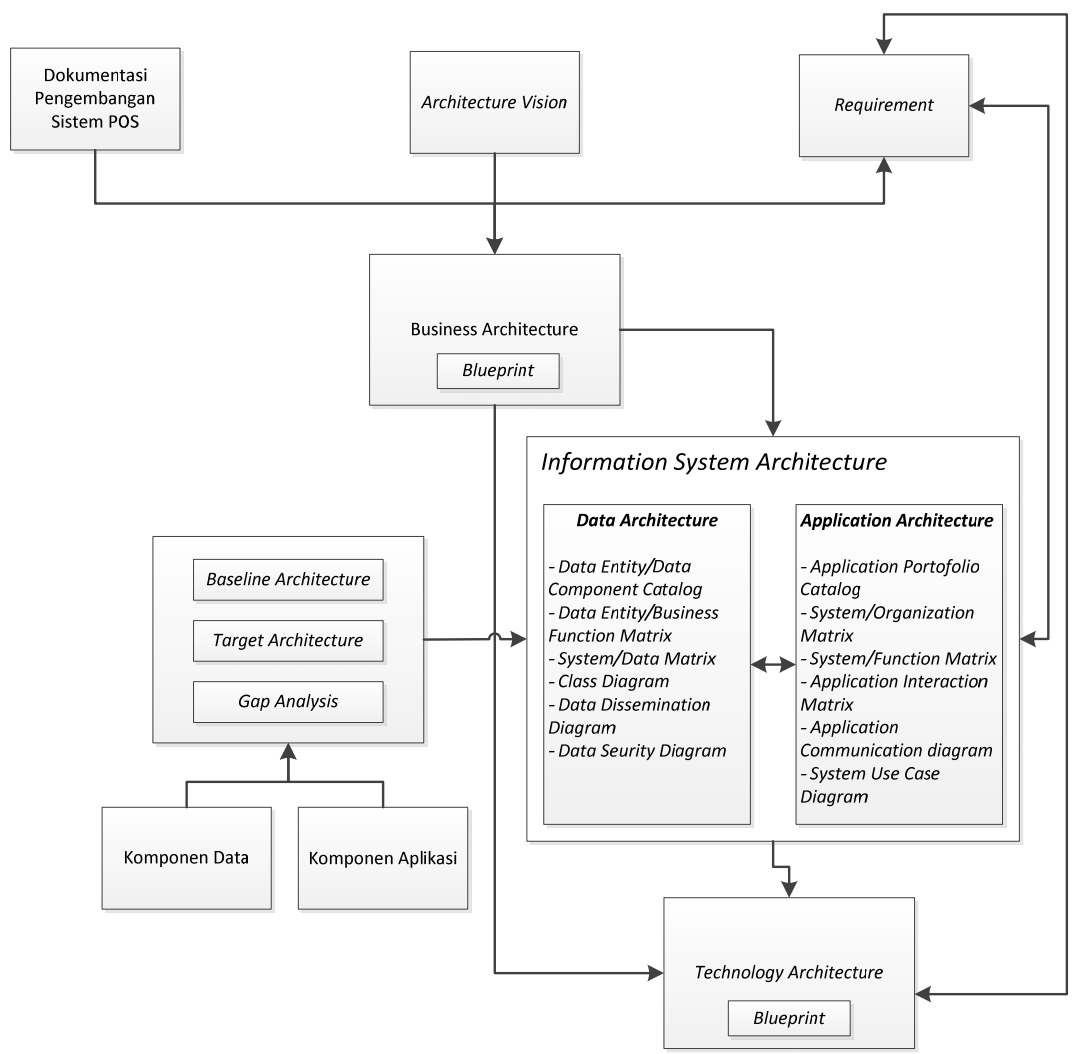

Gambar 1 Model Konseptual 


\section{Kerangka Kerja}

Kerangka kerja yang digunakan mengikuti fase-fase yang ada pada TOGAF ADM. Pengerjaan meliputi preliminary phase, architecture vision, data architecture, dan application architecture. Setiap fase yang dilalui dilakukan identifikasi requirement terlebih dahulu.

Perancangan arsitektur terdiri dari dua komponen, yaitu baseline arsitektur dan target arsitektur. Baseline arsitektur menggambarkan kondisi perusahaan eksisting, sedangkan arsitektur target mendefinisikan kondisi ideal yang diharapkan. Hasil dari perancangan in berupa katalog, matriks, dan diagram yang terdapat pada Tabel I.

TABEL I

ARSITEKTUR BASELINE DAN ARSITEKTUR TARGET

\begin{tabular}{|c|l|l|}
\hline No & Domain Arsitektur & \multicolumn{1}{c|}{ Artifak } \\
\hline 1 & Arsitektur Data & Data entity/data cmponent catalog \\
& & Data entity/business function \\
& & matrix \\
& & System/data matrix \\
& & Class Diagram \\
& & Data Dissemination Diagram \\
& & Data Security Diagram \\
\hline 2 & Arsitektur Aplikasi & Application Portofolio Catalog \\
& & System/Organization Matrix \\
& & System/Function Matrix \\
& & Application Interaction Matrix \\
& & Application Communication \\
& & Diagram \\
& & System Use Case Diagram \\
\hline
\end{tabular}

\section{HASIL DAN PEMBAHASAN}

\section{a. Fase Preliminary}

Fase ini merupakan tahapan menentukan ruang lingkup Enterprise Architecture (EA) yang akan dikembangkan serta menentukan komitmen dengan manajemen dalam pengembangan EA.

TOGAF ADM menyatakan visi dan prinsip yang jelas tentang bagaimana melakukan perancangan enterprise architecture. Prinsip ini digunakan sebagai acuan keberhasilan dalam perancangan arsitektur enterprise. Adapun prinsip arsitektur digambarkan pada Tabel II.

TABEL II

PRINSIP ARSITEKTUR

\begin{tabular}{|c|l|ll|}
\hline No & Prinsip Arsitektur & \multicolumn{2}{|c|}{ Nama Prinsip Arsitektur } \\
\hline 1 & Prinsip Data & 1. & Data adalah sebuah aset \\
& & 2. & Data digunakan bersama \\
& & 3. & Data dapat diakses \\
& & 4. & Pengawasan terhadap data \\
& & 5. & Definisi kosakata dan data yang \\
& & umum \\
\hline 2 & Prinsip Aplikasi & 6. & Keamanan data terjaga \\
\hline & & 2. & Kebebasan Teknologi \\
& & & \\
\hline
\end{tabular}

\section{b. Fase Architecture Vision}

Fase architecture vision merupakan fase inisial dari siklus pengembangan arsitektur seperti identifikasi stakeholders, identifikasi requirement high level, yaitu berupa visi yang ingin dicapai oleh perusahaan. Berikut adalah visi dari PT Shafco Multi Trading adalah:
I. Benar-benar memahami kebutuhan konsumen (fisik, emotional, spiritual \& intelektual).

II. Selalu memberikan solusi kepada para konsumen, dengan metode yang efektif.

\section{c. Fase Business Architecture}

Pada fase ini, dijelaskan mengenai proses bisnis yang ada pada PT Shafco Multi Trading. Dalam menjalankan proses bisnis tersebut, diperlukan data-data yang terkait serta aplikasi sebagai media pengelolaan data tersebut.

Proses bisnis yang ada pada perusahaan sudah didokumentasikan mulai dari inbound logistic, operation, outbound logistic, marketing and sales, service yang dikelompokan ke dalam primary activities serta terdapat juga proses bisnis yang sesuai dengan kategori firm infrastructure, human resource management, technology, procurement yang disebut dengan support activities. Semua proses bisnis tersebut didefinisikan dengan menggunakan value chain porter. Berikut adalah value chain proter dari PT Shafco Mult Trading sesuai pada Gambar 2.

\section{d. Fase Information System Architecture}

Fase ini terdiri dari data architecture dan application architecture. Pada tahap ini baik data architecture maupun application architecture memiliki requirement. Requirement untuk memastikan hasil rancangan penelitian selaras dengan tujuan perusahaan yaitu PT Shafco Multi Trading. Berikut adalah requirement dari data architecture yang sesuai pada Tabel III.

TABEL III

REQUIREMENT DATA ARCHITECTURE

\begin{tabular}{|c|l|}
\hline No & \multicolumn{1}{|c|}{ Requirement Data } \\
\hline 1 & Tidak ada redundansi data \\
\hline 2 & Data dapat diakses sesuai dengan hak ases yang ditentukan \\
\hline 3 & Keamanan data terjaga \\
\hline 4 & Format data yang digunakan bersifat konsisten \\
\hline 5 & $\begin{array}{l}\text { Mampu menghasilkan data untuk setiap fungsi bisnis bila diperlukan } \\
\text { users }\end{array}$ \\
\hline
\end{tabular}

Dalam arsitektur data terdapat beberapa diagram seperti entity relationship diagram serta data dissemination diagram. Entity relationship diagram bertujuan untuk menggambarkan hubungan antar enititas data menggunakan konsep pemodelan diagram chen yang dalam hal ini hubungan antar entitas dijelaskan dengan komponen relasi. Selain itu entitiy relationship diagram juga diartikan teknik yang digunakan untuk memodelkan kebutuhan data dari suatu organisasi, biasanya oleh System Analyst dalam tahap analisis persyaratan proyek pengembangan sistem. Sementara seolah-olah teknik diagram atau alat peraga memberikan dasar untuk desain database relasional yang mendasari sistem informasi yang dikembangkan. ERD yang ada sudah mencakup semua data yang ada pada perusahaan berdasarkan entiitas-entitas data pada perusahaan. Berikut adalah hasil entity relationship diagram pada PT Shafco Multi Trading yang sudah didokumentasi pada penelitian ini yang dijelaskan pada 
Gambar 3. Pada data architecture dibuat pula data dissemination diagram yang bertujuan untuk menggambarkan hubungan entitas data, komponen aplikasi logikal, serta business service. Gambar 4 adalah hasil data dissemination diagram pada PT Shafco Multi Trading.

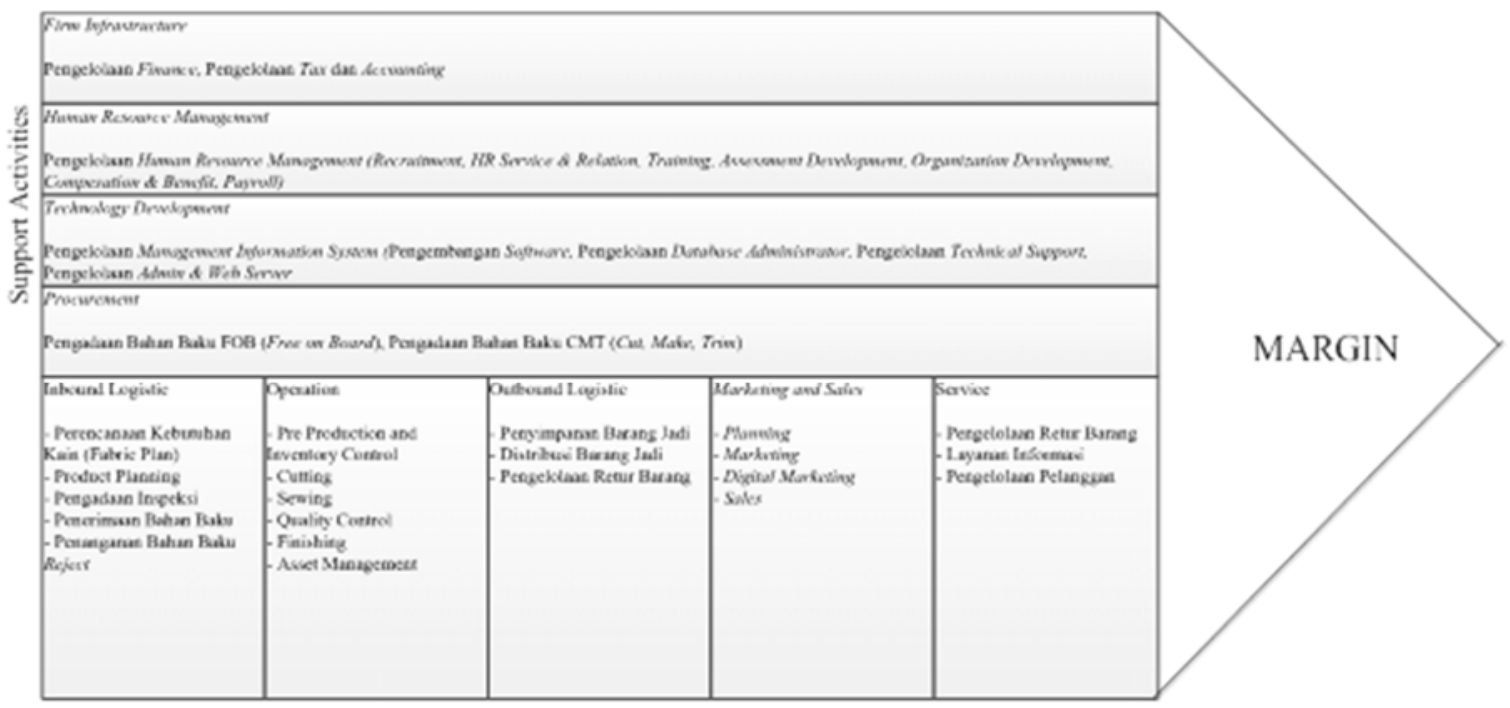

Primary Activities

Gambar 2 Value Chain Proter

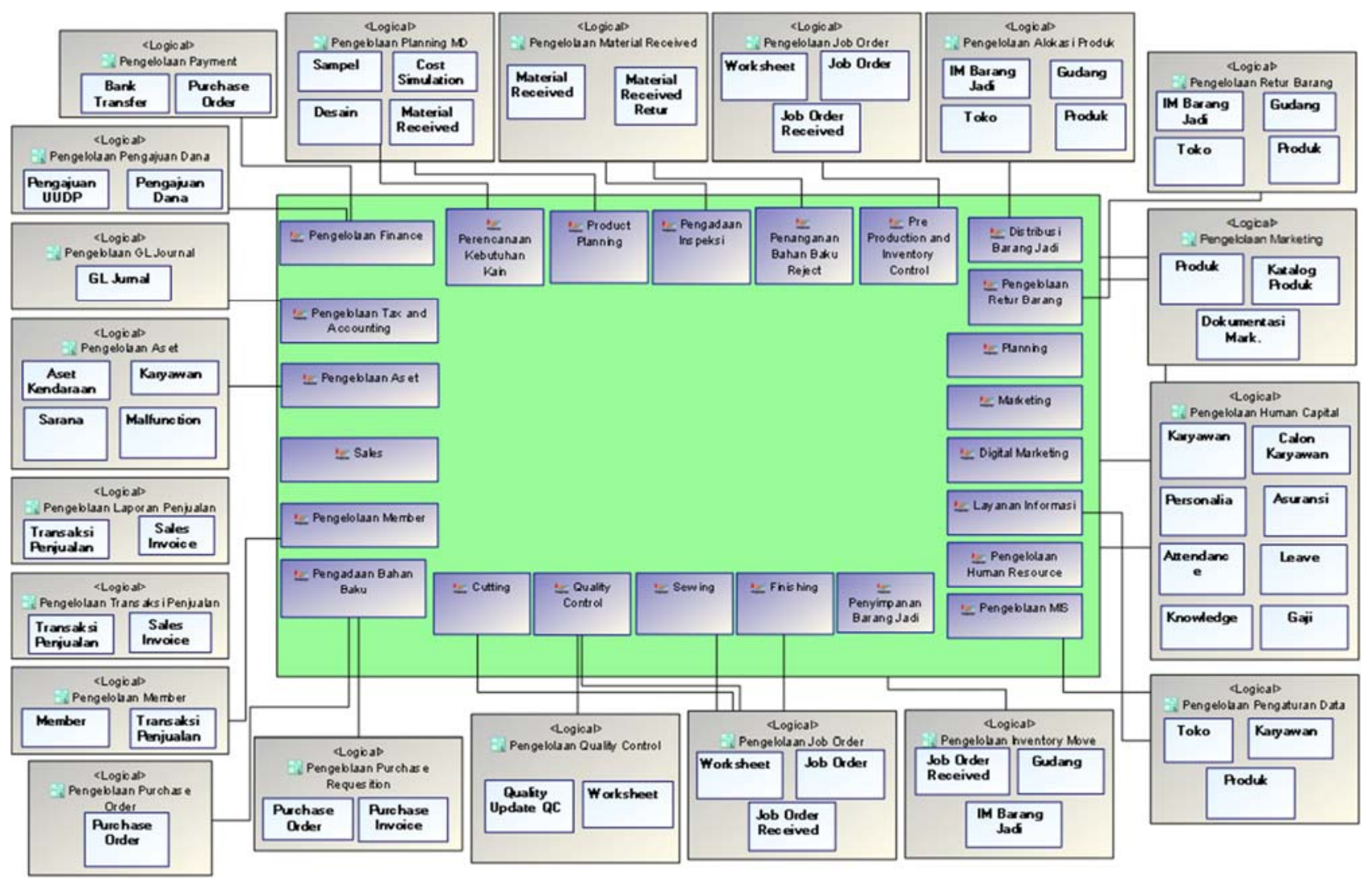

Gambar 3 Entity Relationship Diagram

Analisis dan Perancangan Data Architecture dan Application Architecture menggunakan The Open Group Architecture 


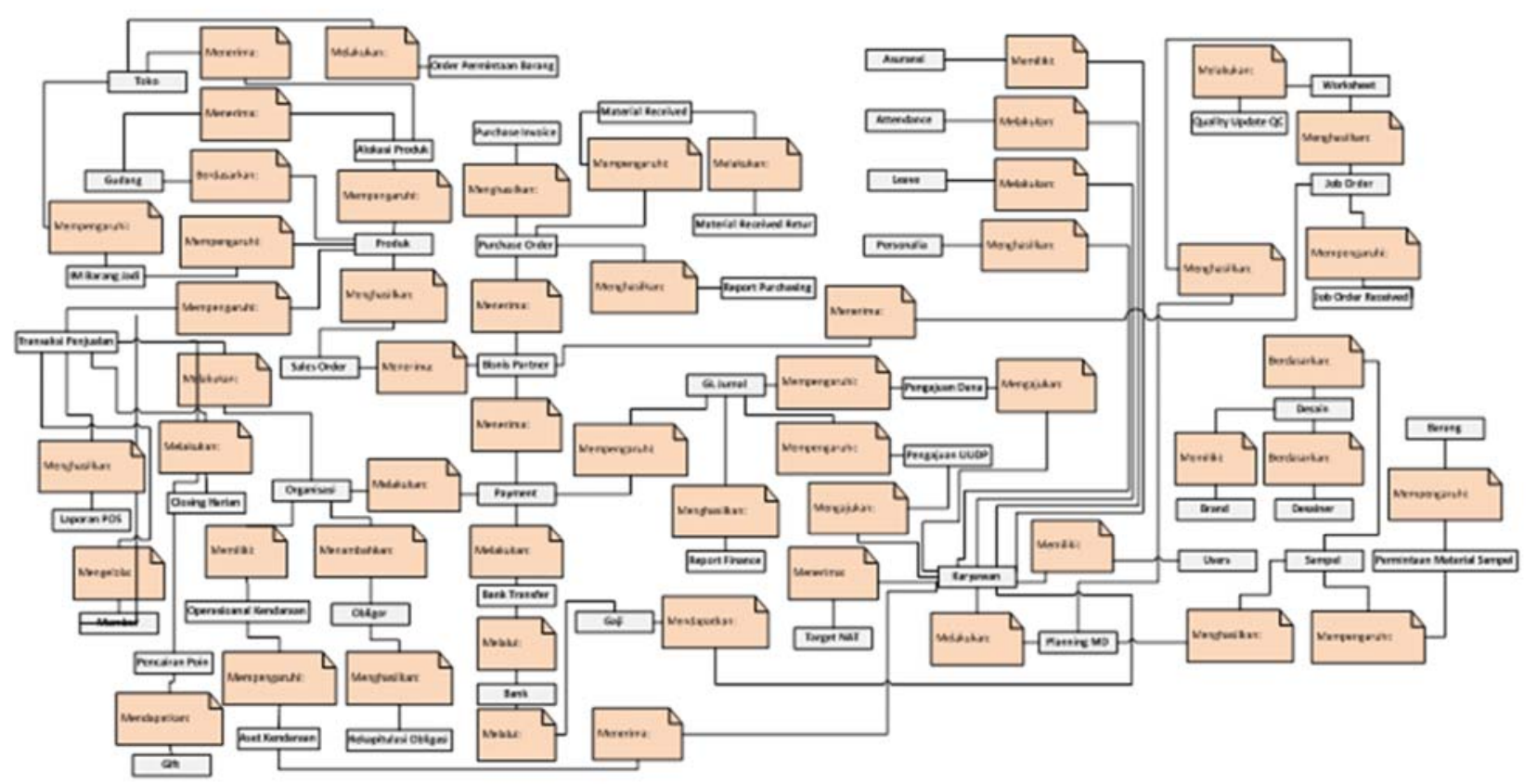

Gambar 4 Data Dissemination Diagram

Pada tahap selanjutnya ada perancangan pada application architecture. Pada tahap ini ditentukan jenis-jenis utama dari sistem aplikasi yang diperlukan untuk memproses data dan mendukung bisnis. Pada tahap ini diharapkan dapat menghasilkan jenis sistem aplikasi yang relevan dengan perusahaan dan apa yang diperlukan untuk dilakukan oleh aplikasi dalam mengelola data dan menyajikan informasi kepada sumber daya manusia dan komputer yang ada di dalam perusahaan. PT Shafco Multi Trading memiliki beberapa aplikasi inti untuk menangani proses bisnis yanga ada seperti aplikasi ERP Shafco yang termasuk di dalamnya juga adalah POS(Point of Sales), HRIS, serta aplikasi penggajian. Pada tahap application architecture juga diperlukan requirement sebagai landasan untuk memastikan bahwa setiap perubahan maupun perancangan sesuai dengan kondisi ideal dari tahap ini. Adapun requirement secara umum mengenai aplikasi pada PT Shafco Multi Trading akan dijelaskan pada Tabel IV.

TABEL IV

REQUIREMENT APPLICATION ARCHITECTURE

\begin{tabular}{|l|l|}
\hline No & \multicolumn{1}{|c|}{ Requirement Aplikasi } \\
\hline \multicolumn{1}{|c|}{ Umum } \\
\hline 1 & Aplikasi relatif mudah untuk digunakan oleh user \\
\hline 2 & $\begin{array}{l}\text { Aplikasi memiliki manual book untuk menjadi panduan } \\
\text { penggunaan oleh user }\end{array}$ \\
\hline 3 & $\begin{array}{l}\text { Semua aplikasi pada perusahaan berbasis web untuk } \\
\text { mempermudah integrasi data yang bersifat real time dan } \\
\text { efesiensi kerja }\end{array}$ \\
\hline
\end{tabular}

Pada application portofolio catalog memiliki bagianbagian seperti komponen aplikasi logikal dan komponen aplikasi fisikal. Komponen aplikasi logikal merupakan gambaran kebutuhan sistem secara logikal melalui fungsi dan layanan yang ada dalam sistem yang dibutuhkan pada setiap kegiatan proses bisnis perusahaan. Berikut adalah komponen aplikasi logikal pada Tabel V.

Pada katalog aplikasi fisikal berisi daftar-daftar dari aplikasi yang berada di dalam arsitektur sistem informasi mencakup semua kegiatan fungsi bisnis yang ada di perusahaan. Berikut adalah komponen aplikasi fisikal pada PT Shafco Multi Trading sesuai dengan Tabel VI.

Dalam penggambaran, matriks application interaction menjadi salah satu matriks yang menjadi deliverable pada perancangan arsitektur ini. Matriks ini bertujuan untuk menggambarkan hubungan antar komponen aplikasi fisikal baseline. Pada tahap ini dapat diketahui komunikasi antar sistem pada PT Shafco Multi Trading. Matriks ini juga membuktikan sistem-sistem yang ada saling berkaitan. Berikut adalah matriks application interaction target pada Tabel VII.

Selain itu, pada tahap application architecture juga terdapat artifak berupa application communication diagram. Tujuan dari perancangan diagram application communication adalah untuk menggambarkan konsep aplikasi pada perusahaan yang dituangkan dalam diagram yang berhubungan dengan semua model dan pemetaan terkait dengan komunikasi antar aplikasi pada entitas metamodel. Diagram ini memperlihatkan komponen aplikasi yang terkait satu sama lain. Berikut adalah application communication diagram pada PT Shafco Multi Trading yang dijelaskan pada Gambar 5. 
TABEL V

KOMPONEN APLIKASI LOGIKAL

\begin{tabular}{|c|c|c|}
\hline & & \\
\hline No. & Nama & Deskripsi \\
\hline \multicolumn{3}{|c|}{ Aplikasi Shafco ERP 3.0.0 } \\
\hline 1 & $\begin{array}{l}\text { Pengelolaan General } \\
\text { Ledge Jurnal }\end{array}$ & $\begin{array}{l}\text { Aplikasi memiliki kemampuan dalam } \\
\text { menangani data jurnal transaksi }\end{array}$ \\
\hline 2 & Pengelolaan Payment & $\begin{array}{l}\text { Aplikasi memiliki kemampuan dalam } \\
\text { menangani pembayaran dan juga } \\
\text { mengakomodasi transkasi transfer dana }\end{array}$ \\
\hline 3 & $\begin{array}{l}\text { Pengelolaan Pengajuan } \\
\text { Dana }\end{array}$ & $\begin{array}{l}\text { Aplikasi memiliki kemampuan dalam } \\
\text { menangani pengajuan dana dari } \\
\text { internal perusahaan baik pengajuan } \\
\text { dana untuk pengadaan maupun UUDP }\end{array}$ \\
\hline 4 & $\begin{array}{l}\text { Pengelolaan Purchase } \\
\text { Order }\end{array}$ & $\begin{array}{l}\text { Aplikasi memiliki kemampuan dalam } \\
\text { menangani pemesanan barang baik } \\
\text { bahan baku maupun barang jadi }\end{array}$ \\
\hline 5 & $\begin{array}{l}\text { Pengelolaan Purchase } \\
\text { Requesition }\end{array}$ & $\begin{array}{l}\text { Aplikasi memiliki kemampuan untuk } \\
\text { menangani requesition approval dan } \\
\text { requesition inventaris }\end{array}$ \\
\hline 6 & $\begin{array}{l}\text { Pengelolaan Report } \\
\text { Purchasing }\end{array}$ & $\begin{array}{l}\text { Aplikasi memiliki kemampuan dalam } \\
\text { membuat laporan purchasing dalam } \\
\text { periode tertentu }\end{array}$ \\
\hline 7 & Pengelolaan Obligasi & $\begin{array}{l}\text { Aplikasi memiliki kemampuan dalam } \\
\text { menangani perjanjian kerja sama } \\
\text { dengan pihak eksternal perusahaan dan } \\
\text { juga dapat merekapitulasi data-data } \\
\text { yang ada pada kegiatan obligasi } \\
\text { perusahaan }\end{array}$ \\
\hline 8 & $\begin{array}{l}\text { Pengelolaan Pengaturan } \\
\text { Data }\end{array}$ & $\begin{array}{l}\text { Aplikasi memiliki kemampuan dalam } \\
\text { menangani pengatura data pada master } \\
\text { data }\end{array}$ \\
\hline 9 & $\begin{array}{l}\text { Pengelolaan Report } \\
\text { Finance }\end{array}$ & $\begin{array}{l}\text { Aplikasi memiliki kemampuan dalam } \\
\text { membuat laporan keuangan berbagai } \\
\text { kategori dalam periode tertentu }\end{array}$ \\
\hline 10 & Pengelolaan Aset & $\begin{array}{l}\text { Aplikasi memiliki kemampuan dalam } \\
\text { menangani aset yang dimiliki } \\
\text { perusahaan }\end{array}$ \\
\hline 11 & $\begin{array}{l}\text { Pengelolaan Planning } \\
M D\end{array}$ & $\begin{array}{l}\text { Aplikasi memiliki kemampuan dalam } \\
\text { menangani perencanaan produksi } \\
\text { barang mulai dari pemilihan desainer, } \\
\text { pencatatan hasil desain, cost } \\
\text { simulation, invoice vendor, permintaan } \\
\text { material sampel, perimntaan material } \\
\text { produksi, serta planning } M D\end{array}$ \\
\hline 12 & Pengelolaan Job Order & $\begin{array}{l}\text { Aplikasi memiliki kemampuan dalam } \\
\text { menangani dokumen yang berkaitan } \\
\text { dengan produksi mulai dari worksheet, } \\
\text { serta job order yang menjadi patokan } \\
\text { produksi antar pihak yang terlibat } \\
\text { dalam proses produksi itu sendiri }\end{array}$ \\
\hline 13 & $\begin{array}{l}\text { Pengelolaan Quality } \\
\text { Control }\end{array}$ & $\begin{array}{l}\text { Aplikasi memiliki kemampuan dalam } \\
\text { melakukan quality control terhadap } \\
\text { hasil produksi }\end{array}$ \\
\hline 14 & $\begin{array}{l}\text { Pengelolaan Alokasi } \\
\text { Produk }\end{array}$ & $\begin{array}{l}\text { Aplikasi memiliki kemampuan dalam } \\
\text { mengelola alokasi produk yang akan } \\
\text { dikirim ke setiap toko }\end{array}$ \\
\hline 15 & $\begin{array}{l}\text { Pengelolaan Inventory } \\
\text { Move }\end{array}$ & $\begin{array}{l}\text { Aplikasi memiliki kemampuan dalam } \\
\text { menangani perpindahan barang dari } \\
\text { tempat satu ke tempat lainnya }\end{array}$ \\
\hline 16 & $\begin{array}{l}\text { Pengelolaan Material } \\
\text { Received }\end{array}$ & $\begin{array}{l}\text { Aplikasi memiliki kemampuan dalam } \\
\text { mencatat material received maupun } \\
\text { material received retur }\end{array}$ \\
\hline 17 & $\begin{array}{l}\text { Pengelolaan Market } \\
\text { Forecast }\end{array}$ & $\begin{array}{l}\text { Aplikasi memiliki kemampuan dalam } \\
\text { melakukan forecast terhadap perjualan }\end{array}$ \\
\hline 18 & Pengelolaan Marketing & $\begin{array}{l}\text { Aplikasi memiliki kemampuan dalam } \\
\text { mengelola dan mendokumentasikan } \\
\text { keperluan pemasaran }\end{array}$ \\
\hline \multicolumn{3}{|c|}{ Aplikasi POS } \\
\hline 19 & $\begin{array}{l}\text { Pengelolaan Transaksi } \\
\text { Penjualan }\end{array}$ & $\begin{array}{l}\text { Aplikasi memiliki kemampuan dalam } \\
\text { menangani transaksi penjualan di toko }\end{array}$ \\
\hline 20 & Pengelolaan Member & Aplikasi memiliki kemampuan dalam \\
\hline
\end{tabular}

\begin{tabular}{|c|c|c|}
\hline No. & Nama & Deskripsi \\
\hline & & $\begin{array}{l}\text { menangani data pelanggan baik profil } \\
\text { pelangan, perpanjangan kartu } \\
\text { pelanggan, maupun pencairan poin }\end{array}$ \\
\hline 21 & $\begin{array}{l}\text { Pengelolaan Retur } \\
\text { Barang }\end{array}$ & $\begin{array}{l}\text { Aplikasi memiliki kemampuan untuk } \\
\text { menangani retur barang baik dari } \\
\text { pelanggan, perpindahan barang dari } \\
\text { toko satu ke toko lainnya, serta retur ke } \\
\text { gudang }\end{array}$ \\
\hline 22 & $\begin{array}{l}\text { Pengelolaan Laporan } \\
\text { Penjualan }\end{array}$ & 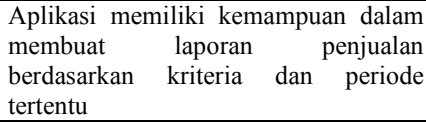 \\
\hline \multicolumn{3}{|c|}{ Aplikasi HRIS } \\
\hline 23 & $\begin{array}{l}\text { Pengelolaan Human } \\
\text { Capital }\end{array}$ & $\begin{array}{l}\text { Aplikasi memiliki kemampuan dalam } \\
\text { menangani data karyawan, kehadiran } \\
\text { karyawan, cuti dan lembur, pemberian } \\
\text { inventaris, pengelolaan knowledge } \\
\text { management, penelitian, penggajian } \\
\text { serta asuransi }\end{array}$ \\
\hline 24 & $\begin{array}{l}\text { Pengelolaan Knowledge } \\
\text { Management }\end{array}$ & $\begin{array}{l}\text { Aplikasi memiliki kemampuan untuk } \\
\text { menyediakan media bagi karyawan } \\
\text { untuk berbagi pengetahuan di dalam } \\
\text { perusahaan }\end{array}$ \\
\hline 25 & Pengelolaan Penelitian & $\begin{array}{l}\text { Aplikasi memiliki kemampuan dalam } \\
\text { mendokumentasikan penelitian yang } \\
\text { diadakan di perusahaan oleh pihak luar }\end{array}$ \\
\hline 26 & Pengelolaan Payroll & $\begin{array}{l}\text { Aplikasi memiliki kemampuan dalam } \\
\text { menangani pemberian gaji pada } \\
\text { karyawan }\end{array}$ \\
\hline
\end{tabular}

TABEL VI

KOMPONEN APLIKASI FISIKAL

\begin{tabular}{|c|c|c|}
\hline No. & Nama & Deskripsi \\
\hline \multicolumn{3}{|c|}{ Aplikasi Shafco ERP 3.0.0 } \\
\hline 1 & $\begin{array}{l}\text { Sistem Accounting \& } \\
\text { Finance }\end{array}$ & $\begin{array}{l}\text { Aplikasi yang mengelola segala jenis } \\
\text { kegiatan yang berhubungan dengan } \\
\text { keuangan mulai dari pengelolaan } \\
\text { jurnal umum, pengajuan dana, serta } \\
\text { juga pembayaran }\end{array}$ \\
\hline 2 & Sistem Purchasing & $\begin{array}{l}\text { Aplikasi yang mengelola segala jenis } \\
\text { pembelian baik dari bahan baku } \\
\text { maupun barang jadi yang terdiri } \\
\text { pengelolaan dokumen purchase order, } \\
\text { purchase invoice, serta hal lainnya } \\
\text { yang berhubungan dengan purchasing }\end{array}$ \\
\hline 3 & Sistem Obligasi & $\begin{array}{l}\text { Aplikasi yang mengelola segala jenis } \\
\text { kerja sama dengan pihak eksternal }\end{array}$ \\
\hline 4 & Sistem Master & $\begin{array}{l}\text { Aplikasi yang mengelola pengaturan } \\
\text { pusat data dari perusahaan }\end{array}$ \\
\hline 5 & $\begin{array}{l}\text { Sistem Asset } \\
\text { Management }\end{array}$ & $\begin{array}{l}\text { Aplikasi yang mengelola aset-aset } \\
\text { perusahaan seperti kendaraan }\end{array}$ \\
\hline 6 & Sistem Produksi & $\begin{array}{l}\text { Aplikasi yang mengelola hal-hal yang } \\
\text { terkait dengan produksi seperti } \\
\text { memprediksi cost simulation, } \\
\text { pembuatan desain oleh desainer, } \\
\text { permintaan material sampel, } \\
\text { permintaan material produksi , } \\
\text { pembuatan invoice vendor, job order, } \\
\text { job order received, planning } \\
\text { MD,pembuatan worksheet, pembuatan } \\
\text { dokumen quality control barang }\end{array}$ \\
\hline 7 & Sistem Warehouse & $\begin{array}{l}\text { Aplikasi yang mengelola hal-hal yang } \\
\text { terkait dengan inventory move, } \\
\text { pencatatan dokumen material received, } \\
\text { alokasi barang }\end{array}$ \\
\hline 8 & Sistem Marketing & $\begin{array}{l}\text { Aplikasi memiliki kemampuan dalam } \\
\text { mengelola dan mendokumentasikan } \\
\text { keperluan pemasaran/iklan }\end{array}$ \\
\hline \multicolumn{3}{|c|}{ Aplikasi POS } \\
\hline 9 & Sistem Sales & Aplikasi yang mengelola hal-hal yang \\
\hline
\end{tabular}




\begin{tabular}{|l|l|l|}
\hline No. & \multicolumn{1}{|c|}{ Nama } & \multicolumn{1}{c|}{ Deskripsi } \\
\hline \multirow{2}{*}{} & & $\begin{array}{l}\text { terkait dengan penjualan seperti } \\
\text { transaksi penjualan, pengelolaan } \\
\text { member, retur barang, closing harian, } \\
\text { target penjualan, serta laporan-laporan } \\
\text { yang terkait penjualan pada periode } \\
\text { tertentu }\end{array}$ \\
\hline Aplikasi Penggajian & \multicolumn{1}{|c|}{} \\
\hline 10 & Sistem Kepegawaian & $\begin{array}{l}\text { Aplikasi yang mengelola hal-hal yang } \\
\text { terkait dengan kepegawaian seperti } \\
\text { profil karyawan, penerimaan } \\
\text { karyawan, penggajian, pengelolaan } \\
\text { knowledge management serta asuransi } \\
\text { karyawan }\end{array}$ \\
\hline
\end{tabular}

TABEL VII

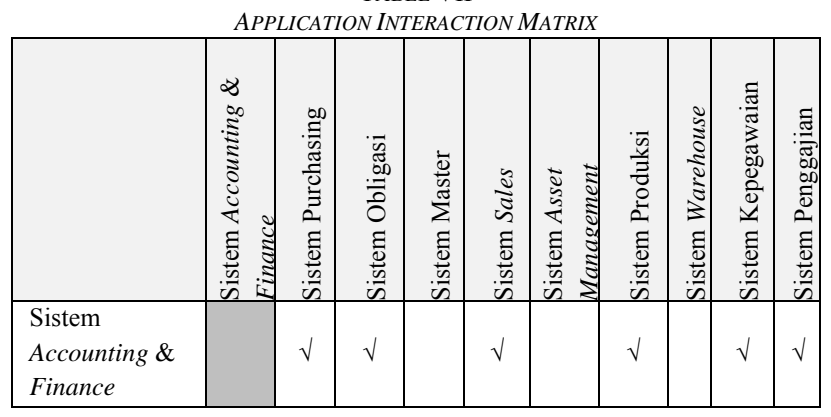

\begin{tabular}{|c|c|c|c|c|c|c|c|c|c|c|}
\hline & 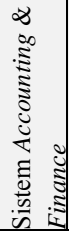 & 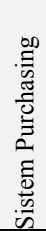 & 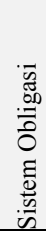 & 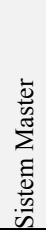 & $\begin{array}{l}\tilde{\tilde{U}} \\
\tilde{\tilde{D}} \\
\tilde{\Xi} \\
\tilde{\tilde{n}} \\
\tilde{n}\end{array}$ & 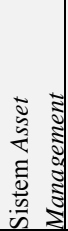 & 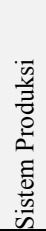 & 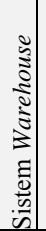 & 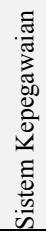 & 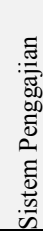 \\
\hline $\begin{array}{l}\text { Sistem } \\
\text { Purchasing }\end{array}$ & $\sqrt{ }$ & & & $\sqrt{ }$ & & & $\sqrt{ }$ & $\sqrt{ }$ & & \\
\hline $\begin{array}{l}\text { Sistem } \\
\text { Obligasi }\end{array}$ & $\sqrt{ }$ & & & & & $\sqrt{ }$ & & & $\sqrt{ }$ & \\
\hline Sistem Master & & & & & & & $\sqrt{ }$ & $\sqrt{ }$ & $\sqrt{ }$ & \\
\hline Sistem Sales & $\sqrt{ }$ & $\sqrt{ }$ & & & & & $\sqrt{ }$ & $\sqrt{ }$ & & \\
\hline $\begin{array}{l}\text { Sistem Asset } \\
\text { Management }\end{array}$ & & & & & & & $\sqrt{ }$ & & $\sqrt{ }$ & \\
\hline $\begin{array}{l}\text { Sistem } \\
\text { Produksi }\end{array}$ & & $\sqrt{ }$ & & & $\sqrt{ }$ & & & $\sqrt{ }$ & & \\
\hline $\begin{array}{l}\text { Sistem } \\
\text { Warehouse }\end{array}$ & & $\sqrt{ }$ & & $\sqrt{ }$ & $\sqrt{ }$ & & $\sqrt{ }$ & & & \\
\hline $\begin{array}{l}\text { Sistem } \\
\text { Kepegawaian }\end{array}$ & & & & $\sqrt{ }$ & & & & & & $\sqrt{ }$ \\
\hline $\begin{array}{l}\text { Sistem } \\
\text { Penggajian }\end{array}$ & $\sqrt{ }$ & & & & & & & & $\sqrt{ }$ & \\
\hline
\end{tabular}

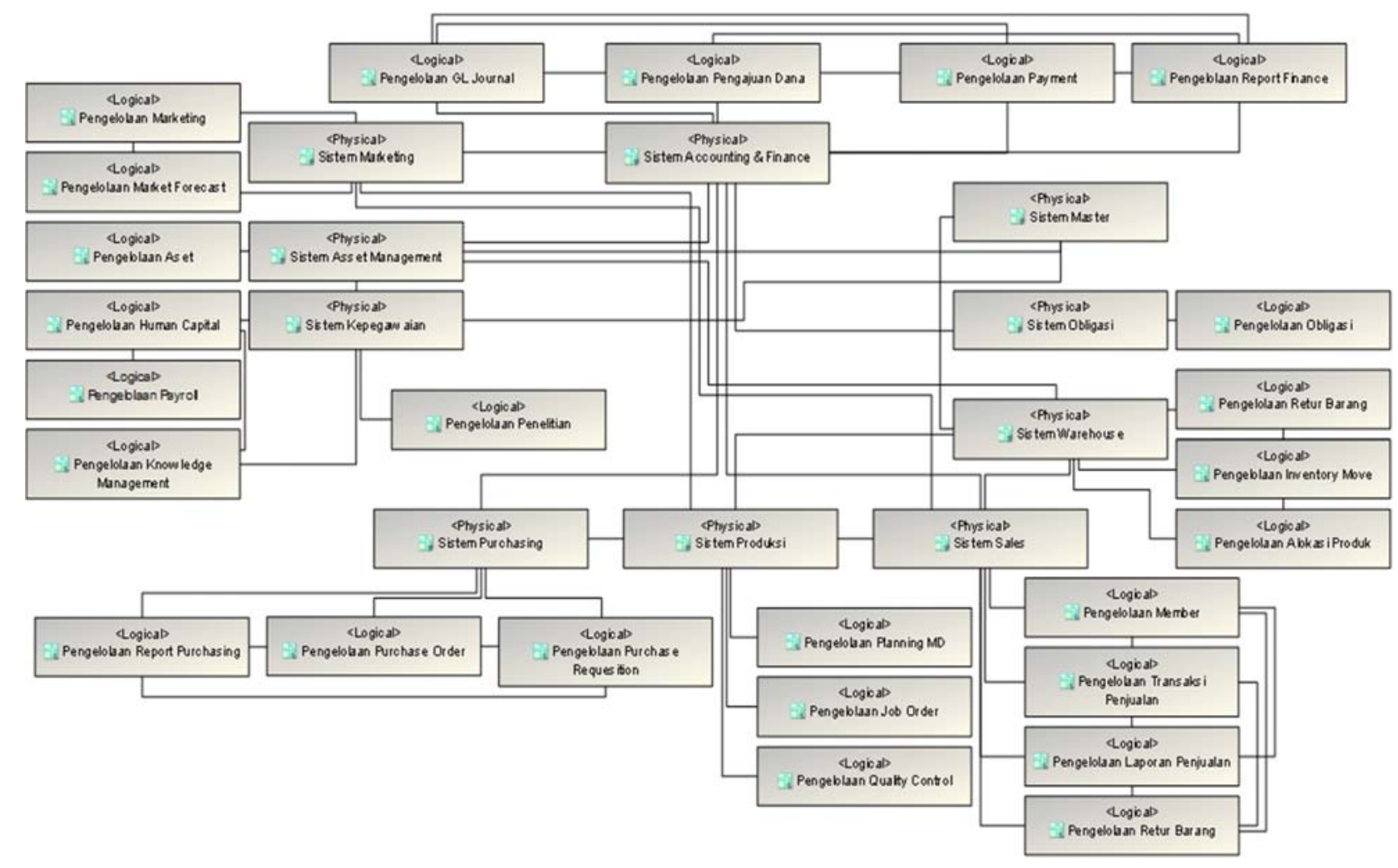

Gambar 5 Application Communication Diagram 


\section{KESIMPULAN}

Penelitian ini menghasilkan dua domian arsitektur, yaitu arsitektur data dan arsitektur aplikasi yang diperlukan oleh PT Shafco Multi Trading dalam penyelarasan bisnis dengan teknologi informasi yang bersinergi dengan visi dari PT Shafco Multi Trading. Dalam analisis dan perancangan kedua domain arsitektur ini sudah sepenuhnya menggunakan alur dan metode yang berasal dari framework TOGAF ADM sehingga dalam penerapannya pada penelitian ini, requirement management menjadi salah satu hal yang sangat penting dalam menjadi acuan pengembangan arsitektur pada perusahaan. Langkah nyata dalam menerapkan requirement management pada penelitian ini adalah selalu melakukan verifikasi dan proses penilaian pada setiap tahap oleh pihak perusahaan sehingga hasil peneliti dapat diterima oleh pihak perusahaan berdasarkan konsep TOGAF ADM yang kami ajukan. Blueprint yang dihasilkan dalam penelitian ini adalah data architecture blueprint yang mendefinisikan komponen data yang digunakan dan dihasilkan perusahaan dalam setiap fungsi bisnis serta application architecture blueprint yang mendefinisikan komponen aplikasi logikal dan komponen aplikasi fisikal sesuai dengan penerapannya dalam memenuhi setiap fungsi bisnis pada PT Shafco Multi Trading.

\section{DAFTAR PUSTAKA}

[1] Chief Information Officer Council, A Practical Guide to Federal Enterprise Architecture, 2001.

[2] P. Weill, MIT Center for Information Systems Research, Barcelona, 2007.

[3] The Open Group, TOGAF Version 9 The Open Group Architecture Framework (TOGAF), 2009.

[4] R. Yunis and Theodora, Penerapan Enterprise Architecture Framework untuk Pemodelan Sistem Informasi, Medan, 2012.

[5] Lise, Comparison of Enterprise Architecture Framework, Issues in Information Systems, Eastern Michigan University Vol. VII, 2006. 